УДК 655.254.22:[681.85:81'25

() О. В. Тріщук, д.н. із соц. ком., професор, О. Ю. Януль, аспірантка, КПІ ім. Ігоря Сікорського, Київ, Україна

\title{
РЕДАКТОРСЬКА ПІДГОТОВКА ПЕРЕКЛАДІВ НАУКОВО-ПОПУЛЯРНИХ СЕРІАЛІВ
}

Виявлено специфіку перекладного науково-популярного серіалу та окреслено загальні підходи до його редагування.

Досліджено роль редактора на всіх етапах створення перекладу науково-популярного серіалу, зокрема, під час:

1) усебічного аналізу першоджерела задля з'ясування особливостей твору, важливих для подальшого опрацювання тексту; 2) написання перекладу та його редагування; 3) запису аудіодоріжки (назвучування).

Ключові слова: науково-популярний серіал; аудіовізуальний твір; переклад; редакторська підготовка перекладу; редактор.

\section{Постановка проблеми}

Стрімкий розвиток науки й техніки в сучасному світі та підвищена увага суспільства до новітніх розробок активізують потребу в науково-популярних творах, які подають наукові знання з тієї чи іншої галузі, адаптовані до сприйняття і розуміння читачанефахівця. Науково-популярні твори відіграють вирішальну роль у пропагуванні знань, залученні людей до набутків прогресу у сфері науки, культури й техніки, утім, незважаючи на це, не отримали достатнього висвітлення в працях сучасних науковців питання, що стосуються особливостей їх редакторського опрацювання. Передусім бракує ґрунтовних напрацювань щодо редагування перекладних науковопопулярних аудіовізуальних творів, від якості якого залежить сприйняття їх реципієнтом. Це зумов- лює необхідність виявити особливості цього аудіовізуального продукту, дослідити їх вплив на процес перекладу, що підтверджує актуальність обраної теми.

Теоретичною основою дослідження стали напрацювання вітчизняних і зарубіжних науковців з царин перекладацької діяльності [1-10], випуску та особливостей науково-популярної літератури [11-16]; редакторських аспектів роботи над перекладами [10, 17].

Цінними для нас $€$ праці тих дослідників, що вивчали аудіовізуальну форму подання інформації. Окремі аспекти перекладу аудіовізуальних творів висвітлено в працях А. Мельника [8], А. Кулікової та Ю. Головачової [7], В. Вострецової [18]. Різним видам аудіовізуального перекладу присвячено збірник 'Audiovisual

(C) $2017 p$. 
Translation. Language Transferon Screen' за редакцією X. Сінтаса та Г. Андерман [19], стандартам субтитрування - публікацію 'A Proposed Setof Subtitling Standardsin Europe' [20]. Особливості роботи редактора перекладу з телевізійним художнім текстом розглянуто Р. Сегол [21].

\section{Мета роботи}

Виявити специфіку перекладного науково-популярного серіалу та окреслити загальні підходи до його редагування.

\section{Результати проведених досліджень}

Науково-популярний серіал це аудіовізуальний твір, спрямований на популяризацію наукових фактів, теорій і відкриттів. Він $є$ основним джерелом інформації для комунікування науковців 3 людьми, які цікавляться науковими дослідженнями, але не володіють спеціальною термінологією, оскільки не $є$ фахівцями в цій галузі.

Серіал складається 3 деякої кількості об'єднаних тематикою, сюжетом, героями (за наявності) й однакових за довжиною та форматом серій. Головним героєм у ньому $є$ оповідач (ведучий), а сюжетний аспект відображається в логіці викладу теми протягом усього твору.

Науково-популярний серіал як феномен аудіовізуальної комунікації складається 3 відеоряду зі змінними зображеннями та словесного ряду (тексту), тобто має візуальний і звуковий складники, які обов'язково постають у взаємодії задля формування цілісного аудіовізуального образу. Оптимізація цієї взаємо- дії набуває особливого значення під час створення перекладу іншомовних науково-популярних серіалів задля їх адаптування для аудиторії, що не $є$ носієм мови оригіналу.

Нерозривна єдність вербальної та невербальної інформації зумовлює особливості опрацювання серіалу редактором перекладу, основними з яких є такі:

- синхронне передавання змісту та різних кодів (зображення в русі, нерухоме зображення, текст, музика, шум) через слуховий та зоровий канали;

- підпорядкування перекладу зображенню, оскільки саме воно є незмінним;

- залучення до процесу перекладу як власне перекладачів та редакторів, так і режисерів, акторів, що зумовлює внесення додаткових корективів у текст;

- технічний складник, тобто спосіб відтворення перекладу [8, C. 111].

Отримати якісний переклад науково-популярного серіалу можна лише завдяки спільній роботі редактора й решти команди, залученої до створення адекватного друготвору, адже тільки в поєднанні талантів усіх учасників цього процесу з'являється досконало відтворений продукт, який належно сприйме україномовна аудиторія.

Забезпечити адекватність перекладу оригіналові - одне 3 основних завдань редактора. Вона полягає у вичерпній передачі основного змісту, форми, емоційно-оцінного та естетичного складників першоджерела засобами іншої мови з дотриманням рівноваги між цілим та окремим і передбачає однакове 
розуміння вміщених у первинному творі та його перекладі як експліцитно вираженої інформації, так і підтексту. Між перекладним текстом і його сприймачем має виникати такий самий зв'язок, який існував між первинним твором і його реципієнтом.

Для отримання адекватного перекладу передусім потрібна співпраця редактора й перекладача, яка має бути зорієнтована на об'єднання індивідуальних зусиль кожного для досягнення найкращого результату. Оскільки всі зусилля перекладача спрямовані на досягнення досконалості серіалу й редактор також має на меті максимально його оптимізувати, то вони стають союзниками й творчими партнерами.

Успішному співробітництву цих суб'єктів комунікаційного процесу перетворення тексту телесеріалу на текст друготвору сприяють:

- концентрація уваги на вирішенні спільної проблеми, а не на прагненні самореалізуватися та довести іншому комунікантові його некомпетентність;

- сприйнятливість і неупередженість;

- взаємозалежність у досягненні кінцевого результату, схильність до спільної роботи в майбутньому, спрямованість на добрі стосунки. Однак, ця спрямованість не має бути важливішою, ніж досягнення позитивного кінцевого результату.

Роль редактора важлива на всіх трьох етапах створення перекладу науково-популярного серіалу:

1) усебічного аналізу першоджерела задля з'ясування особ- ливостей твору, важливих для подальшого опрацювання тексту;

2) створення перекладу та його редагування;

3) запису аудіодоріжки (назвучування).

Ця роль на першому етапі полягає у визначенні особливостей твору й обговоренні з перекладачем майбутньої роботи над адаптацією тексту. Навіть за умови, що редактор не спілкується безпосередньо з перекладачем та отримує для опрацювання створений без його участі переклад, він все одно повинен самостійно проаналізувати твір. В іншому разі він не зможе критично оцінити переклад і врахувати особливості науково-популярного серіалу як цілісного аудіовізуального продукту.

Для створення адекватного адаптованого перекладу потрібен аналіз граматичних особливостей оригінального твору (переважання простих чи складних речень, частота вживання вставних конструкцій тощо), який дозволяє оцінити, як часто доведеться застосовувати переставляння, додавання та вилучення, наскільки це може порушити синхронізацію з візуальним складником, і як компенсувати це порушення.

Також важливо з'ясувати, яку роль відіграє емоційно-експресивний складник в аудіовізуальному творі. Якщо він $€$ одним 3 основних популяризаторських прийомів, то його адекватній адаптації варто приділити особливу увагу. Якщо ж виклад підкреслено «сухий» (що іноді трапляється в науково-популярному серіалі), тоді під час перекладу необхідно буде відтворити лише раціонально-логічну інформацію. 
Один з визначальних факторів впливу на специфіку перекладу та його редагування лексика твору. Під час аналізу мови серіалу редакторові необхідно оцінити складність термінів, насиченість тексту ними, їх повторюваність, ілюстрування на екрані тощо. Це дає можливість:

- визначити, які терміни в оригіналі $€$ багатозначними, які з них мають омоніми в мові перекладу, що дасть можливість адекватно їх відтворити;

- звести термінологічну основу перекладу до єдиного набору термінів задля уникнення синонімічних понять;

- 3'ясувати, які терміни вживаються в обох мовах, а які не притаманні мові перекладу, і вирішити, чи варто вводити в текст пояснення терміна, чи можна замінити його загальним поняттям.

Додаткових зусиль від перекладача та редактора перекладу науково-популярного серіалу вимагає насиченість тексту реаліями, які потребують пояснення для іншомовної аудиторії. Реалії, або безеквівалентну лексику, науковці визначають як одиниці мови, які виникають у результаті історичного розвитку народу, позначають явища та умови побуту, властиві культурі цього народу [22, С. 139]. Складність їх перекладу виникає внаслідок браку фонових знань культури, у межах якої постав оригінал. Такими, наприклад, можуть бути поняття на позначення явищ та предметів культури в історичних науково-популярних серіалах чи одиниці вимірювання, що використовуються в США, Канаді, а для української аудиторії, яка мислить у метричній системі, викликають труднощі для сприймання.

Якщо безеквівалентні лексеми трапляються в серіалах украй рідко і не відіграють важливої ролі, їх можна замінити загальними поняттями або ж опустити, якщо при цьому зберігається раціонально-логічний складник повідомлення. У тому випадку, коли вони $є$ істотними для розуміння твору або самі стають предметом розповіді, їх адаптування стає одним з першочергових завдань редактора та перекладача.

Важливими для розгляду вважаємо також власні назви й сталі словосполучення, від ролі та частоти вживання яких залежить вибір того чи іншого способу перекладу. Під час опрацювання цих одиниць необхідно враховувати:

- наявність однозначного відповідника (чи його традиційно закріпленого варіанта, що частково відрізняється за написанням або вимовою) для власних назв та еквівалента для сталих словосполучень у мові перекладу;

- наявність традиційних для мови перекладу аналогів, які несуть те саме смислове й емоційно-експресивне навантаження. Необхідно враховувати, що часом образні засоби в носіїв різних культур можуть передавати неоднакові чи навіть протилежні значення: іноді те, що в одних народів вважається позитивом, в інших $€$ негативним явищем;

- брак готового відповідника, що зумовлює потребу знайти оптимальний спосіб адаптування. 
Аудіовізуальна форма подання інформації ставить особливі вимоги до адаптування науковопопулярного твору. Для збереження синхронності тексту та зображення на екрані потрібно підлаштовувати переклад до картинки, оскільки візуальний складник у серіалі не може бути змінений.

Аналіз тексту науково-популярного серіалу дозволяє обрати оптимальний спосіб відтворення його перекладу (субтитрування, назвучування чи повне дублювання), вибір якого залежить від специфіки першотвору, його жанру, лексичних і синтаксичних особливостей, часу, відведеного на його підготовку тощо.

Під час редакторського аналізу цього аудіовізуального твору необхідно оцінити, наскільки часто бачимо текстову інформацію у візуальному складникові (назви будівель, написи на пакованні тощо). Це дозволить обрати адекватний варіант її відтворення для глядача, який не $€$ носієм мови оригіналу й не може самостійно зрозуміти зміст тексту.

Якісно проведений усебічний аналіз твору полегшує його подальше опрацювання та дає можливість:

- з'ясувати, скільки часу потрібно для створення перекладу;

- виявити, консультація яких фахівців знадобиться для створення адекватного перекладу;

- зрозуміти, якими словниками, довідниками та базами даних доведеться користуватися (термінологічними словниками різних галузей, словниками фразеологізмів, іншомовних слів, географічних назв, імен людей, прислів'їв і приказок, електронними словниковими ресурсами тощо);

- визначити, яким має бути процес назвучування;

- скласти оптимальний план роботи над адаптацією тексту науково-популярного серіалу та розподілити обов'язки.

На другому етапі відбувається написання тексту перекладу (робота перекладача) та його вдосконалення (робота редактора перекладу). До перекладу серіалів зі складною науковою тематикою варто залучати провідних фахівців галузі, які зможуть об'єктивно оцінити зміст усього аудіовізуального науково-популярного твору та окремих його інформаційних блоків.

Для багатосерійних аудіовізуальних творів $€$ три варіанти проходження цього етапу:

- перекладач створює переклад до всіх серій, після чого його опрацьовує редактор перекладу;

- усі серії опрацьовують почергово (переклад першої серії його редагування, далі переклад другої - редагування і т. д.);

- постійна спільна робота перекладача та редактора перекладу над серіалом.

Незалежно від того, який варіант обрано, кожний етап повинен завершуватися обговоренням редакторських правок з перекладачем. Завдання редактора піднести перекладача до такого високого ступеня професіоналізму, коли той зможе подивитися на власний матеріал очима редактора. Тобто йдеться не про підміну редактором перекладача, а про посилення його ролі 
в перекладацькому процесі 3 урахуванням усіх завдань, що об'єктивно стоять перед ним.

Редактор повинен уміти правильно визначити, де й у чому перекладач відійшов від тих вимог, які висуваються до науковопопулярного викладу. Після цього він вносить правки в текст, чітко аргументуючи їx, щоб перекладач був повністю переконаний в їх доцільності.

На третьому етапі (запис аудіодоріжки) ключовими комунікантами $€$ режисер назвучування та актори, однак робота редактора перекладу не менш значуща. Навіть за умови попереднього детального обговорення особливостей тексту всією командою і надання рекомендацій для режисера й акторів від перекладача та редактора перекладу, під час запису аудіодоріжки можуть виникати додаткові питання, виявлятися неточності в тексті тощо. Крім того, варто враховувати можливість акторських обмовок чи неправильного прочитання перекладу. Тому редактор перекладу, який знає всю специфіку аудіального науковопопулярного твору та розуміє його зміст, має бути в студії та критично оцінювати роботу решти працівників. Важливою $€$ також його участь у зведенні окремих елементів у цілісну аудіодоріжку, а також у їі монтуванні задля забезпечення відповідності звуку візуальному складникові.

Варіант, коли редактор опрацьовує вже записану аудіодоріжку, не вважаємо оптимальним, адже в разі виявлення помилок буде складніше й дорожче вносити зміни в готовий продукт, ніж одразу перезаписувати окремі репліки під час роботи над чорновою версією.

Редакторської уваги на цьому етапі створення серіалу потребує кількість героїв у творі, яка зумовлює й кількість акторів назвучуванні. Якщо вона не однакова, глядач перекладного твору має чути перехід від мови одного героя до мови іншого. Крім того, необхідно зберегти інтонаційний малюнок тексту оригіналу, тож у тексті для назвучування варто робити позначки для актора щодо пауз, вимови тощо.

\section{Висновки}

Участь редактора у створенні адекватного перекладу науковопопулярного аудіовізуального твору $€$ важливою на кожному етапі: від першого перегляду оригінального продукту до монтування готового аудіозапису мовою перекладу. Це оптимізує роботу всієї команди й дає можливість виправляти помилки одразу ж після їх виникнення, що дозволяє отримати якісний результат без багаторазового перероблення тексту та аудіозапису.

Оскільки візуальний складник науково-популярного серіалу підкріплює його текстову частину, а це зумовлює необхідність зберігати у творі синхронізацію та заради неї адаптувати текст перекладу, то редактор має менше можливостей модифікувати матеріал саріалу, ніж звичайної науково-популярної статті. Це підтверджує необхідність подальших наукових пошуків для напрацювання ефективних прийомів редагування перекладу за цих обставин. 


\section{Список використаної літератури}

1. Влахов С. Непереводимое в переводе / С. Влахов, С. Флорин. - 2-е изд., испр. и доп. - М. : Высш. шк., 1986. - 416 с.

2. Галь Н. Слово живое и мертвое : из опыта переводчика и редактора / Н. Галь. - 3-е изд., доп. - М. : Книга, 1979. - 208 с.

3. Зарицький М. С. Переклад : створення та редагування / М. С. Зарицький. - Київ : Парлам. вид-во, 2004. - 120 с.

4. Зорівчак Р. П. Реалія і переклад (на матеріалі англомовних перекладів української прози) / Р. П. Зорівчак. - Львів : Вид-во при Львів. держ. ун-ті, 1989. $-216 \mathrm{c}$.

5. Комиссаров В. Н. Лингвистика перевода / В. Н. Комиссаров. - М. : Междунар. отношения, 1980. - 168 с.

6. Корунець І. В. Розрізнення термінів «адекватний переклад», «еквівалентний переклад», «реалістичний переклад», «точний переклад» (до ідентифікації понять) / І. В. Корунець // Наук. записки : зб. наук. пр. - Київ : Міжнар. ін-т лінгвістики і права, 2001. - С. 289-291.

7. Кулікова А. $Є$. Перекладацька компресія міжмовних субтитрів художніх фільмів / А. Є. Кулікова, Ю. О. Головачова // Вісн. Луган. нац. ун-ту ім. Тараса Шевченка. - Сер. Філол. науки. - 2013. - № 9. - 4. 1. - С. 53-58.

8. Мельник А. П. Кінопереклад як особливий тип аудіовізуального перекладу / А. П. Мельник // Наук. зап. Нац. ун-ту «Острозька академія». Сер. Філологія. - 2015. - Вип. 58. - С. 110-112.

9. Михайленко О. О. Англомовна науково-популярна стаття в українському та російському перекладах / О.О.Михайленко // Актуальні проблеми укр. лінгвістики : теорія і практика. - 2015. - Вип. 31. - С. 84-95.

10. Райт-Ковалева Р. Нить Ариадны / Р. Райт-Ковалева // Редактор и перевод : сб. статей. - М., 1965. - С. 3-23.

11. Романчук О. Роль науково-популярної літератури у пропаганді знань / О. Романчук // Вісник Львів. ун-ту. - Сер. Журналістика. - Львів, 2011. Вип. 34. - С. 188-194.

12. Сухая Е. В. Жанровые аспекты популярных произведений о науке / Е. В. Сухая // Жанры и типы текста в научном и медийном дискурсе : межвуз. сб. науч. тр. / отв. ред. А. Г. Пастухов ; Орловский гос. ин-т искусств и культуры, 2012. - Вып. 9. - С. 189-197.

13. Хомутова Т. Н. Научно-популярный текст : интегральная модель / Т. Н. Хомутова, С. Г. Петров // Вестн. Южно-Уральского гос. ун-та. - Сер. Лингвистика. - 2013. - Т. 10. - № 2. - С. 37-41.

14. Cooter R. Separate spheres and public places: Reflections on the history of science popularization and science in popular culture / R. Cooter, S. Pumfrey // History of Science. - 1994. - \# 32. - P. 237-267.

15. Gregory J. Science in Public / J. Gregory, S. Miller. - New York: Basic Books, 2000. - 369 p.

16. Nisbet M. C. What's next for science communication? Promising directions and lingering distractions / M. C. Nisbet, D. A. Scheufele // American journal of botany. - 2009. - \# 96(10). - P. 1767-1778.

17. Партико 3. В. Норми редагування перекладів / 3. В. Партико // Вісник Кн. палати. - 2013. - № 7. - С. 9-13.

18. Вострецова В. О. Алюзії в аудіовізуальному перекладі / В. О. Вострецова // Наук. зап. Ніжин. держ. ун-ту ім. Миколи Гоголя. - Сер. Філол. науки. $-2014 .-$ Кн. 3. - С. 46-49. 
19. Audiovisual translation: language transfer on screen / edited by Jorge Diaz Cintas and GunillaAnderman. - Basingstoke: Palgrave Macmillian, 2009. $256 \mathrm{p}$.

20. Karamitroglou F. A proposed set of subtitling standards in Europe / F. Karamitroglou // Translation journal: website. - 1998. - URL: http://translationjournal.net.

21. Сегол Р. І. Редагування перекладу текстів англомовних телесеріалів : дис. ... канд. наук із соц. комунікацій : 27.00 .05 / Р. І. Сегол. - Київ, 2010. $206 \mathrm{c}$.

22. Щеголєва Т. Л. Способи перекладу безеквівалентної лексики в текстах американської преси / Т. Л. Щеголєва // Наук. вісн. Міжнарод. гуманіт. ун-ту. - Сер. Філологія. - 2016. — № 21. - Том 1. - С. 139-142.

\section{References}

1. Vlahov, S. \& Florin, S. (1986). Neperevodimoe v perevode [Untranslatable in the translation]. Moscow: Vysshaja shkola [in Russian].

2. Gal', N. (1979). Slovo zhivoe i mertvoe: iz opyta perevodchika i redaktora [Words living and words dead: from the experience of an interpreter and editor]. Moscow: Kniga [in Russian].

3. Zarytskyi, M. S. (2004). Pereklad: stvorennia ta redahuvannia [Translation: creating and editing]. Kyiv: Parlamentske vydavnytstvo [in Ukrainian].

4. Zorivchak, R. P. (1989). Realiia i pereklad (na materiali anhlomovnykh perekladiv ukrainskoi prozy) [Reality and translation (based on English translations of Ukrainian prose)]. Lviv: Vyd-vo pry Lviv. derzh. un-ti [in Ukrainian].

5. Komissarov, V. N. (1980). Lingvistika perevoda [Linguistics in translation]. Moscow: Mezhdunar. otnoshenija [in Russian].

6. Korunets, I. V. (2001). Rozriznennia terminiv 'adekvatnyi pereklad', 'ekvivalentnyi pereklad', 'realistychnyi pereklad', 'tochnyi pereklad' (do identyfikatsii poniat) [The distinction between the terms 'adequate translation', 'equivalent translation', 'realistic translation', 'exact translation' (to the identification of concepts)]. Journal of Nauk. zapysky - Scientific papers, 289-291 [in Ukrainian].

7. Kulikova, A. le. \& Holovachova, lu. O. (2013). Perekladatska kompresiia mizhmovnykh subtytriv khudozhnikh filmiv [Translational compression in crosslanguage subtitles for the feature films]. Journal of Visn. Luhan. nats. un-tu im. Tarasa Shevchenka. Ser. Filol. nauky - Bulletin of Taras Shevchenko National University of Luhansk, Phililogy Sciences series, 9, Part 1, 53-58 [in Ukrainian].

8. Melnyk, A. P. (2015). Kinopereklad yak osoblyvyi typ audiovizualnoho perekladu [Cinematic translation as a particular type of audiovisual translation]. Journal of Nauk. zap. Nats. un-tu 'Ostrozka akademiia'. Ser. Filolohiia Scientific papers of National University 'Ostroh Academy', Philology series, 58, 110-112 [in Ukrainian].

9. Mykhailenko, O. O. (2015). Anhlomovna naukovo-populiarna stattia v ukrainskomu ta rosiiskomu perekladakh [English popular science article in Ukrainian and English translations]. Journal of Aktualni problemy ukr. linhvistyky: teoriia i praktyka - Actual issues of the Ukrainian linguistics: theory and practice, 31, 84-95 [in Ukrainian].

10. Rajt-Kovaleva, R. (1965). Nit' Ariadny [Ariadna's thread]. Journal of Redaktor i perevod - Editor and translation, 3-23 [in Russian].

11. Romanchuk, O. (2011). Rol naukovo-populiarnoi literatury u propahandi znan [Role of popular science literature in knowledge propagation]. Journal of Visnyk Lviv. un-tu. Ser. Zhurnalistyka - Bulletin of Lviv University, Journalism series, 34, 188-194 [in Ukrainian]. 
12. Suhaja, E. V. (2012). Zhanrovye aspekty populjarnyh proizvedenij o nauke [Genre aspects of popular works about science]. Journal of Zhanry i tipy teksta v nauchnom i medijnom diskurse - Genres and types of texts in scientific and media discourse, 9, 189-197 [in Russian].

13. Homutova, T. N. \& Petrov, S. G. (2013). Nauchno-populjarnyj tekst: integral'naja model' [Popular science text: integral model]. Journal of Vestn. Juzhno-Ural'skogo gos. un-ta. Ser. Lingvistika - Bulletin of South Ural State University, Linguistics series, 2, Vol. 10, 37-41 [in Russian].

14. Cooter, R. \& Pumfrey, S. (1994). Separate spheres and public places: Reflections on the history of science popularization and science in popular culture. Journal of History of Science, 32, 237-267 [in English].

15. Gregory, J. \& Miller, S. (2000). Science in public. New York: Basic Books [in English].

16. Nisbet, M. C. \& Scheufele, D. A. (2009). What's next for science communication? Promising directions and lingering distractions. Journal of American journal of botany, 96(10), 1767-1778 [in English].

17. Partyko, Z. V. (2013). Normy redahuvannia perekladiv [Standards of editing of translations]. Journal of Visnyk Kn. palaty - Bulletin of Book Chamber of Ukraine, 7, 9-13 [in Ukrainian].

18. Vostretsova, V. O. (2014). Aliuzii v audiovizualnomu perekladi [Allusions in audiovisual translation]. Journal of Nauk. zap. Nizhyn. derzh. un-tu im. Mykoly Hoholia. Ser. Filol. nauky - Scientific papers of Nizhyn Gogol State University, Philology Sciences series, Book 3, 46-49 [in Ukrainian].

19. Cintas, J. D. (Ed.) \& Anderman, G. (Ed.) (2009). Audiovisual translation: language transfer on screen. Basingstoke: Palgrave Macmillian [in English].

20. Karamitroglou, F. (1998). A proposed set of subtitling standards in Europe. Retrieved from http://translationjournal.net/journal/04stndrd.htm (accessed 30 October 2016) [in English].

21. Sehol, R. I. (2010). Redahuvannia perekladu tekstiv anhlomovnykh teleserialiv [Editing of translation for television series texts]. Thesis for Candidate's Degree in Social Communications by specialty 27.00.05, National Technical University of Ukraine 'Kyiv Polytechnic Institute']. Kyiv [in Ukrainian].

22. Shcheholieva, T. L. (2016). Sposoby perekladu bezekvivalentnoi leksyky $v$ tekstakh amerykanskoi presy [Ways of translation of culture-specific vocabulary in American press texts]. Journal of Nauk. visn. Mizhnarod. humanit. un-tu. Ser. Filolohiia - Scientific papers of International Humanitarian University, Philology series, 21,Vol. 1, 139-142 [in Ukrainian].

\footnotetext{
Выявлена специфика переводного научно-популярного сериала и намечены общие подходы к его редактированию. Исследована роль редактора на всех этапах создания перевода научно-популярного сериала, в частности, при: 1) всестороннем анализе первоисточника для выяснения особенностей произведения, важных для дальнейшей обработки текста; 2) написании перевода и его редактировании; 3) записи аудиодорожки (озвучивания).
} 


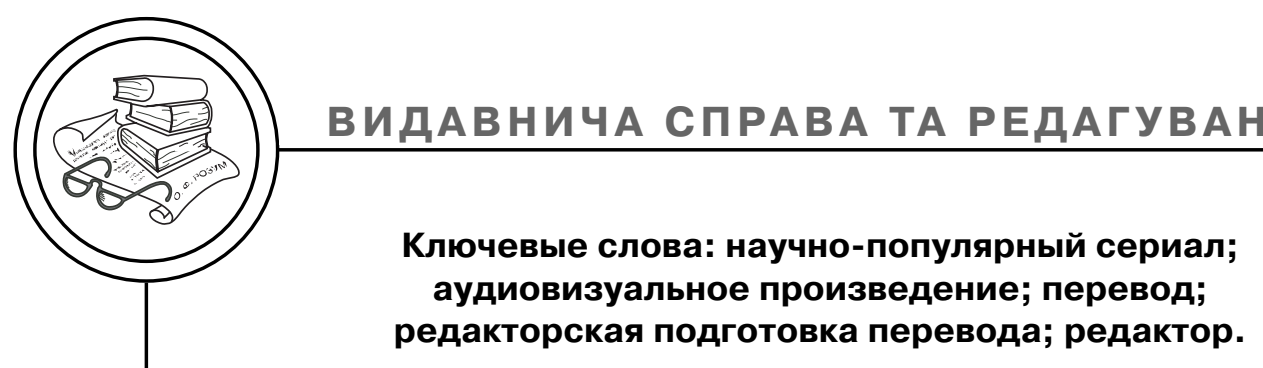

The specifics of popular science television series are revealed and the general approaches to editing of this kind of products are outlined. The role of the editor at all stages of the creation of the translation for popular science television seriesis examined, in particular during: 1) comprehensive analysis of the original product in order to find out its features that are important for the further work on the text;

2) creating the translation and its editing; 3 ) recording the audio track (voice-over).

Keywords: popular science series; audiovisual product; translation; editorial preparation of translation; editor.

Рецензент - Н. М. Фіголь, к.філол.н., доцент, КПІ ім. Ігоря Сікорського

Надійшла до редакції 22.01.17

72 